\title{
$\mathrm{SD600}$ 철근의 B급 겹침 이음에 대한 현행설계기준의 적용성
}

\author{
최원석 ${ }^{1)} \cdot$ 정 란 $^{2)} \cdot$ 김진근 ${ }^{3)} \cdot$ 박홍근 $^{1) *}$ \\ ${ }^{1)}$ 서울대학교 건축학과 ${ }^{2)}$ 단국대학교 건축공학과 ${ }^{3)}$ 한국과학기술원 건설및환경공학과
}

\section{Applicability of Current Design Code to Class B Splice of SD600 Re-Bars}

\author{
Won-Seok Choi, ${ }^{1)}$ Lan Chung, ${ }^{2)}$ Jin-Keun Kim, ${ }^{3)}$ and Hong-Gun Park ${ }^{1) *}$ \\ ${ }^{1)}$ Dept. of Architecture \& Architectural Engineering, Seoul National University, Seoul 151-744, Korea \\ ${ }^{2}$ Dept. of Architectural Engineering, Dankook University, Yongin 448-701, Korea \\ ${ }^{33}$ Dept. of Civil and Environmental Engineering, Korea Advanced Institute of Science and Technology, Daejeon 305-701, Korea
}

\begin{abstract}
An experimental study was performed to evaluate the applicability of current design code to the class B splice of SD600 reinforcing bars. Twelve simply supported beam and slab specimens with re-bar splices were tested under monotonic loading. Parameters for this test were re-bar diameter, concrete cover thickness, concrete strength, and stirrup spacing. Concrete strengths ranged 24.7 55.3 MPa. Most of the specimens were designed to satisfy the class B splice length specified by current design code. Average bar stresses resulting from this test were compared with the predictions by the KCI code provisions. Based on the result, the applicability of the current design code to SD600 re-bars were evaluated. The re-bar splices gave satisfactory performance for all D13 re-bar splices and for D22 and D32 splices with transverse reinforcement. On the basis of the test result, for D22 and the greater diameter bars, the use of either transverse reinforcement of the thicker concrete cover was recommended.
\end{abstract}

Keywords : SD600, high strength steel, splice length, bond, class B splice

\section{1. 서 론}

현행 $\mathrm{KCI}$ 콘크리트 구조설계기준 ${ }^{1)}$ 에서는 철근의 최대 설계기준항복 강도를 $550 \mathrm{MPa}$ 로 규정하고 있으며, 현재 이를 $600 \mathrm{MPa}$ 철근(SD600)으로 변경하기 위한 기준의 개정 작업이 진행중이다. 고강도 철근을 사용할 때 적절 한 겹침 이음 성능의 확보는 구조 안전성을 위한 가장 기본적인 요구 사항 중 하나이므로 설계기준 개정에서 중요하게 고려되어야 한다. 현행 $\mathrm{KCI}$ 설계기준 ${ }^{1)}$ 과 동일 한 $\mathrm{ACI} 318$ 설계기준 ${ }^{2}$ 의 겹침 이음 길이 관련 규정은 $\mathrm{ACI}$ Committee $408^{3,4)}$ 에 보고된 방대한 양의 실험 결과에 기 초를 두고 있지만 설계기준 항복 강도 $560 \mathrm{MPa}$ 이상의 철근에 대한 겹침 이음 실험 결과는 매우 제한적이다.

국내에서는 이재훈 등히이 SD600과 SD700 철근의 겹 침 이음에 대한 현행 설계기준 ${ }^{1)}$ 의 적용성을 평가하였다. 실험체의 변수는 겹침 이음 철근의 설계기준 항복 강도 가 $400 \mathrm{MPa}, 600 \mathrm{MPa}, 700 \mathrm{MPa}$ 이며, 콘크리트의 압축강 도를 $36 \mathrm{MPa}, 70 \mathrm{MPa}$ 로 조합하여 6 개의 겹침 이음 실험체 를 제작하였다. 철근으로서 $\mathrm{D} 22$ 와 $\mathrm{D} 25$ 를 사용하였으며,

*Corresponding author E-mail : parkhg@snu.ac.kr Received January 24, 2011, Revised May 13, 2011, Accepted May 26, 2011

(c) 2011 by Korea Concrete Institute
겹침 이음 길이로서 $12 d_{b}$ 와 $10 d_{b}$ 를 사용하였다. 모든 실 험체는 이음 길이에 $200 \mathrm{~mm}$ 간격으로 2 개의 띠철근을 배치하였다. 겹침 이음 길이의 발현 평균 부착 응력 대 예측 평균 부착 응력의 비 $\left(U_{\text {test }} / U_{\text {cal }}\right)$ 를 현행 설계기준 $\left.{ }^{1}\right)$ 을 기반으로 분석한 결과 1.3 이상의 안전율을 나타내었다. 그러나 이 실험에서는 겹침 이음 길이를 SD600, SD700 철근에 소요되는 길이보다 짧게 제작하였으며, 이로 인 하여 철근의 발현 응력이 $175 \sim 268 \mathrm{MPa}$ 로 설계기준 항복 강도 $600 \mathrm{MPa}$ 에 크게 미치지 못하므로 실제 겹침 이음 의 거동과 차이가 있다.

캐나다와 미국에서는 El-Hacha 등이 고강도 철근의 부 착 특성을 연구하였다. 실험에 사용한 $\mathrm{MMFX}$ 철근은 Fig. 1 과 같이 항복 구간이 불명확하기 때문에 $0.2 \%$ offset 방법 으로 항복 강도를 정의하였으며, 철근 No.19(직경 $19 \mathrm{~mm}$ ) 와 No.25의 항복 강도와 인장강도는 $827 \mathrm{MPa}, 1,127 \mathrm{MPa}$ 이었다. 콘크리트 강도는 $41.8 \mathrm{MPa}$ 이었다. 겹침 이음 길이 는 No.19에 대하여 $305 \sim 1,524 \mathrm{~mm}$, No.25에 대하여 305 $1,829 \mathrm{~mm}$ 의 범위였다. 실험 결과, 철근의 발현 응력은 No.19 의 경우 430.82 830.62 MPa이었으며, No.25의 경우 337.77 $954.74 \mathrm{MPa}$ 로 나타났다. $\mathrm{ACI} 318^{2)}$ 의 $\mathrm{A}$ 급 이음으로 철근 의 발현 응력 대 예측 응력 비 $\left(f_{s, t e s t} / f_{s, c a l}\right)$ 를 분석한 결 과 $550 \mathrm{MPa}$ 이하에서는 $\mathrm{ACI} 318^{2)}$ 이 안전측이었으나 높 은 철근 응력이 발현될 경우는 안전측이 아닌 것으로 나 


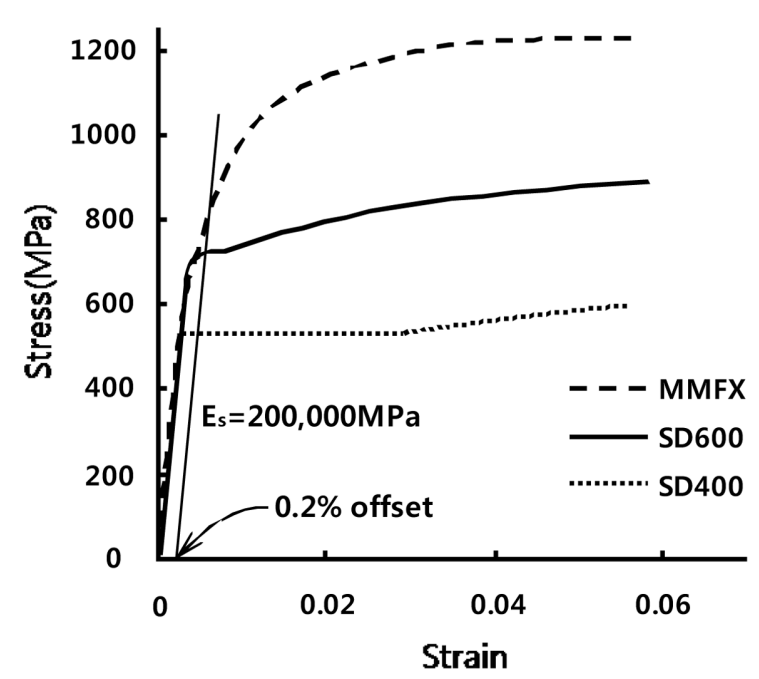

Fig. 1 Stress-strain relationships of SD600/D22, SD400/D22 and MMFX steel

타났다. El-Hacha 등은 MMFX철근의 높은 응력 수준에 서 발현되는 응력-변형률 관계의 강한 비선형성 때문에 $\mathrm{ACI} 318^{2}$ 을 안전측으로 적용할 수 없는 것으로 분석하였다.

최근에는 Seliem 등ㄲㅇㅣ 69개의 MMFX 철근 겹침 이음 실험을 수행한 연구 결과가 발표되었다. Seliem 등ㄲ은 이 연구를 통하여 설계기준 항복 강도가 $550 \mathrm{MPa}$ 이상인 철 근의 겹침 이음에 대한 $\mathrm{ACI} 318^{2)}$ (식 (1))과 $\mathrm{ACI} 408 \mathrm{R}-03^{4)}$ (식 (A1))의 적용성을 평가하였다. 실험에 사용된 $\mathrm{MMFX}$ 철근은 $0.2 \%$ offset 방법으로 정의한 항복 강도가 $830 \mathrm{MPa}$ 이며, 인장강도가 $1,125 \mathrm{MPa}$ 이다. 실험의 주요 변수는 철 근 직경, 이음 길이, 횡보강 철근량, 콘크리트 강도이었 다. 철근으로서 No.16, No.25, No.36을 사용하였으며, 콘 크리트의 설계 압축강도는 $35 \mathrm{MPa}$ 과 $55 \mathrm{MPa}$ 이었다. 이 음 길이는 횡보강 철근이 없을때 $\mathrm{ACI} 408 \mathrm{R}-03^{4}(\phi=1.0)$ 에 기반하여 $555 \mathrm{MPa}$ 또는 $690 \mathrm{MPa}$ 의 철근 응력이 발현되 도록 설계하였다. $\left.\mathrm{ACl} 318^{2}\right)$ 의 $\mathrm{A}$ 급 이음에 기반하여 철근의
발현 응력 대 예측 응력 비 $\left(f_{s, t e s t} / f_{s, c a l}\right)$ 를 분석한 결과 횡 보강 철근이 없는 경우는 평균이 0.87 이고 대부분이 1 미만으로 안전측이 아니었으며, 최소값은 0.61 이었다. 횡 보강 철근을 배치한 경우는 평균이 1.10 이고 실험체의 반 이상이 안전측이 아니었으며, 최소값이 0.66 이었다. 반면에 ACI408R- $03^{4}(\phi=0.82)$ 에 기초한 철근의 발현 응 력 대 예측 응력 비 $\left(f_{s, t e s t} / f_{s, c a l}\right)$ 는 거의 모든 실험체에서 1 이상으로 안전측의 결과를 나타내었다. 횡보강 철근이 없 는 경우는 평균이 1.19 이고 최소값이 0.92 이었으며, 횡보 강 철근을 배치한 경우는 평균이 1.29 이고 최소값이 1.03 이었다.

이 연구의 목적은 $\mathrm{SD} 600$ 철근의 겹침 이음에 대한 현 행 $\mathrm{KCI}$ 설계기준 ${ }^{1)}$ 의 적용성을 평가하는 것이다. 일반적 으로 휨부재의 휨강도는 콘크리트가 아닌 철근에 의하여 지배를 받으므로 보통 강도 콘크리트가 흔히 사용된다. 그러나 고강도 철근에 대한 기존 연구들에서는 일반적으 로 사용되는 $30 \mathrm{MPa}$ 이하 강도의 콘크리트에 대한 실험 결과가 없다. 또한, 기존 연구의 결과에 따르면, 철근의 직경이 클수록 겹침 이음의 성능이 취약한 경향성이 확인 되었다. 따라서 이 연구에서는 $30 \mathrm{MPa}$ 이하의 보통 강도 콘크리트와 굵은 직경의 SD600철근에 대한 겹침 이음 실험을 집중적으로 수행하였다.

\section{2. 실험 및 분석의 고려 사항}

이 연구에서는 고강도 철근의 겹침 이음에 대한 선행 연구와 현행 $\mathrm{ACI} 318^{2)}$ 에 대한 연구 자료를 바탕으로 $\mathrm{SD} 600$ 철근의 겹침 이음에 대한 현행 설계기준 ${ }^{1}$ 의 적용 성을 적절히 평가하기 위하여 다음과 같은 세 가지 사 항을 고려하였다(실험체는 Fig. 2 참조).

첫째, 겹침 이음 실험을 $\mathrm{B}$ 급 이음으로 분석하였다. 현 행 설계기준 ${ }^{1)}$ 에서 $\mathrm{A}$ 급 이음은 $1.0 l_{d}\left(l_{d}=\right.$ 기본량 설계 $), \mathrm{B}$ 급 이음은 $1.3 l_{d}$ 를 적용하도록 규정하고 있으며, $\mathrm{A}$ 급 이

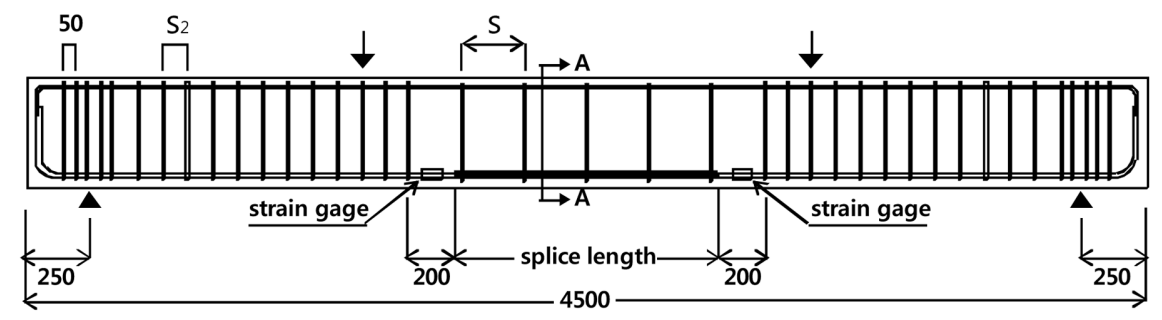

(a) Beam specimen

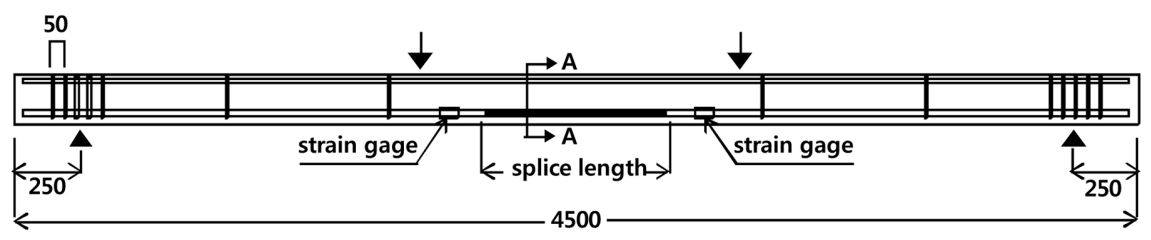

(b) Slab specimen

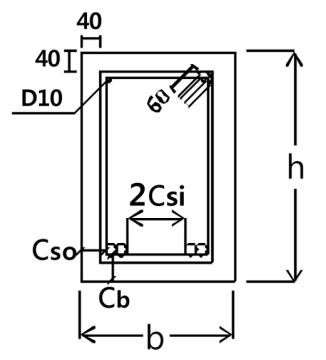

A-A section

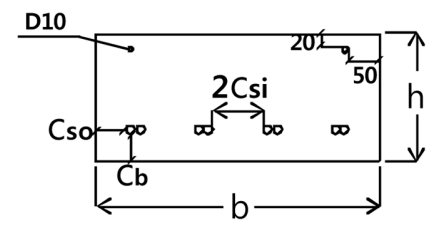

A-A section

Fig. 2 Dimensions and reinforcement details of test specimens 
음은 다음의 조건을 모두 만족하는 경우에 해당된다. (1) 배치된 철근량이 이음부 전체 구간에서 해석 결과 요구 되는 소요 철근량의 2 배 이상인 경우, (2) 소요 겹침 이 음 길이 내 겹침 이음된 철근량이 전체 철근량의 $1 / 2$ 이 하인 경우. 이와 같이 $\mathrm{A}$ 급 이음에는 제한이 많기 때문에 일반적으로 시공성 확보를 위하여 대부분의 현장에서 $\mathrm{B}$ 급 이음이 사용되고 있다. 이 연구와 ACI Committee $408^{3,4}$ 에 보고된 기존 실험들은 모든 주철근을 같은 위치에서 이 음하고, 겹침 이음 구간의 파괴가 발생할 때 까지 휨모 멘트를 작용시키기 때문에 $\mathrm{B}$ 급 이음에 해당된다. 따라서 고강도 철근에 대한 선행 연구들에서는 겹침 이음 실험을 $\mathrm{A}$ 급 이음으로 분석하였으나 이 연구에서는 $\mathrm{B}$ 급 이음계 수 $1.3 l_{d}$ 을 적용하여 현행 설계기준 ${ }^{1)}$ 의 적용성을 평가하 였다. 또한 이 실험 결과와 함께 Seliem 등긔 $\mathrm{MMFX}$ 고 강도 철근에 대한 기존의 실험 자료를 현행 기준 ${ }^{1}$ 의 $\mathrm{B}$ 급 이음으로 분석하였다(기존 연구에서는 $\mathrm{A}$ 급 이음으로 분석함).

둘째, 현행 설계기준 ${ }^{1)}$ 을 만족하도록 실제 겹침 이음 길 이를 사용하였다. ACI408R-03 $03^{4}$ 과 Orangun 등 ${ }^{8}$ 에 따르면 기존의 보통 강도 철근에 대한 연구들에서는 이음 길이를 설계기준보다 짧게 설계하여 실험하였다. 그러나 ACI408R$03^{4)}$ 에 따르면 현행 설계기준 ${ }^{1}$ 은 이음 길이가 길어지고 철 근의 발현 응력이 커질수록 안전율이 낮아지는 경향이 있다. 따라서 이 연구에서는 SD600 철근에 대한 정확한 적용성 평가를 위하여 현행설계기준 ${ }^{1}$ 의 $\mathrm{B}$ 급 이음길이 $1.3 l_{d}$ 를 만족하는 실제 크기의 실험체를 계획하였다.

셋째, $\mathrm{SD} 600$ 철근의 겹침 이음에 대한 현행 설계기준 ${ }^{1}$ 의 적용성을 평가하는 적절한 방법과 기준이 필요하다. 기존의 보통 강도 철근에 대한 설계기준의 적용성 평가 에서는 ACI Committee $408^{3,4)}$ 의 방대한 실험 자료를 통 계적으로 분석하는 방법을 사용하였다. 겹침 이음 철근 의 설계기준 항복 강도와 관계없이 모든 실험 자료의 발 현 응력 대 예측 응력 비 $\left(f_{s, t e s t} / f_{s, \text { cal }}=U_{s, \text { test }} / U_{s, \text { cal }}\right)$ 의 분 포를 분석하고 적절한 수준의 강도 감소 계수 $\phi$ 를 결정 하였다. ACI 408R-793에 따르면 현행 설계기준 ${ }^{1)}$ 은 Fig. $3^{10}$ 과 같이 $\phi=0.8$ 이 식 자체에 적용된 형태이며, 이 값은 발현 응력 대 예측 응력의 비가 평균적으로 1.25 이고 대부 분이 1 이상이 되도록 규정한 것이다. 그러나 이 분석 결

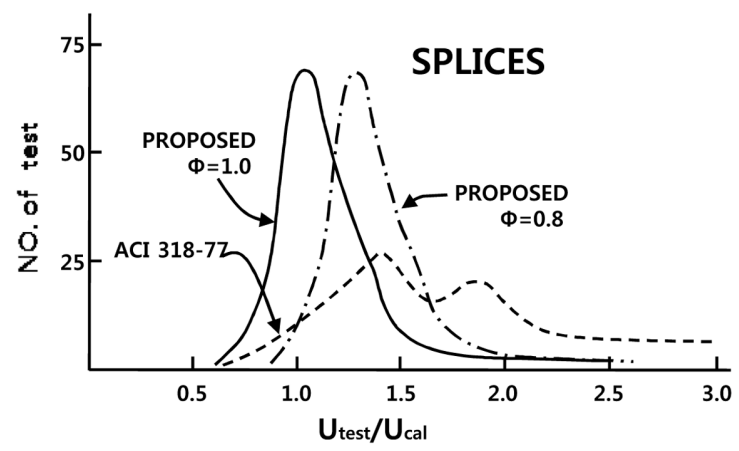

Fig. 3 Developed/calculated average bond stress ratios reported in $\mathrm{ACl} 408 \mathrm{R}-79$
과는 저강도를 포함하는 모든 응력 범위에 대한 자료로 서 실제로 철근 응력이 증가할수록 안전율은 저하되는 문제점을 가지고 있다(Fig. $3^{10)}$ 에 나타난 바와 같이 일부 실험체에 대해서는 안전측이 아님). 이 연구에서는 고강 도 철근에 대한 제한된 실험체 수의 결과를 가지고 현 행 설계기준 ${ }^{1}$ 의 적용성을 평가해야 하기 때문에 통계적 방법보다는 각 개별 실험체에 대하여 철근의 설계기준 항 복 강도 이상에서 발현 응력 대 예측 응력비가 1 이상 $\left(f_{\text {stest }}\right)$ $\left.f_{s, c a l} \geq 1.0\right)$ 일 때 안전한 것으로 판단하였다. 또한 기존의 실험과 달리 이 연구는 현행 설계기준ํㅡㄹ 만족하도록 겹 침 이음 길이를 설계하였으므로 철근이 항복하는 경우에 는 최대 부착 응력이 저평가될 수 있으며, 따라서 발현 응력 대 예측 응력비가 보수적으로 평가될 수 있다.

\section{SD600 철근의 응력-변형률 관계}

SD600 철근의 응력-변형률 관계의 특성을 파악하기 위 하여 실험에 사용된 SD600 철근의 인장 시험을 수행하 였다. 각 철근 시험편의 길이는 $800 \mathrm{~mm}$ 이고, 시험편 축 방향 길이의 중앙에 변형률 게이지를 부착하여 응력-변형 률 관계를 측정하였다. Fig. 1은 이 연구에서 측정한 $\mathrm{SD} 400$, $\mathrm{SD} 600$ 철근과 선행 연구에서 측정한 MMFX철근의 응력변형률 관계를 나타내었다. SD600철근은 강도와 응력-변 형률 관계의 비선형성 측면에서 $\mathrm{SD} 400$ 철근과 $\mathrm{MMFX}$ 철 근의 중간적인 특징을 나타내었다. SD600철근의 응력-변 형률 관계는 초기 탄성계수 $\left(E_{s}\right)$ 가 보통 강도 철근과 동 일한 $200 \mathrm{GPa}$ 이며, 설계기준 항복 강도 $600 \mathrm{MPa}$ 까지 선 형에 가까운 것으로 나타났다. 또한 SD400철근에 비하 여 항복 마루가 짧고, 항복 마루가 발생하기 이전에 비 선형성이 발현되는 특징이 있다. SD600/D13, D22, D32의 실제 항복 응력 $f_{y, t \text { test }}$ 은 각각 $650 \mathrm{MPa}, 720 \mathrm{MPa}, 700 \mathrm{MPa}$ 이고, 인장강도 $f_{u, t e s t}$ 는 $805 \mathrm{MPa}, 892 \mathrm{MPa}, 858 \mathrm{MPa}$ 이었다.

\section{4. 실험 계획}

이 연구는 SD600철근을 주철근으로 사용하여 실물 크 기의 겹침 이음 실험을 계획하였다. 모든 실험체는 인장 지배 단면으로 설계하였으며, 대부분의 실험체는 현행 설 계기준 ${ }^{1}$ 의 $\mathrm{B}$ 급 이음길이를 만족하도록 설계하였다. 주철 근은 모두 실험체 중앙에서 겹침 이음하였으며, Fig. 2와 같이 2점 재하하여 겹침 이음 구간에서 파괴가 발생할 때까지 등분포 모멘트를 작용시켰다.

실험체 형태는 보 또는 슬래브로 구분하여 계획하였으 며, 보 실험체는 단면에 2 개, 슬래브 실험체는 단면에 4 개 의 겹침 이음을 배치하였다. 모든 실험체의 길이는 $4,500 \mathrm{~mm}$ 이며, 인장 지배 단면이 되도록 설계한 실험체의 단면 크 기 $(b \times h)$ 는 Table 1 에 나타내었다. 모든 실험체는 2 개의 $\mathrm{SD} 400 / \mathrm{D} 10$ 철근을 압축 철근으로 사용하였으며, 겹침 이 음 구간 내에 횡보강 철근이 있는 실험체는 $\mathrm{SD} 400 / \mathrm{D} 10$ 철 근을 Table 1 의 $s$ 간격으로 배근하였다. 보 실험체의 경우 
Table 1 Design properties of test specimens

\begin{tabular}{|c|c|c|c|c|c|c|c|c|c|c|c|c|c|c|c|}
\hline \multirow{2}{*}{$\begin{array}{c}\text { Specimens } \\
\text { ID }\end{array}$} & \multirow{2}{*}{$\begin{array}{c}\text { Specified } \\
\text { concrete } \\
\text { strength } \\
f_{c k} \\
(\mathrm{MPa})\end{array}$} & \multirow{2}{*}{$\begin{array}{c}\text { Re-bars } \\
\left(f_{y}=600\right. \\
\mathrm{MPa}) \\
\text { bar } \\
\text { diameter } \\
d_{b}\end{array}$} & \multirow{2}{*}{\begin{tabular}{|} 
Type of \\
specimen
\end{tabular}} & \multirow{2}{*}{$\begin{array}{c}\text { Width } \\
b \\
(\mathrm{~mm})\end{array}$} & \multirow{2}{*}{$\begin{array}{c}\text { Depth } \\
h \\
(\mathrm{~mm})\end{array}$} & \multirow{2}{*}{$\begin{array}{c}c^{(2)} \\
(\mathrm{mm})\end{array}$} & \multicolumn{3}{|c|}{$\begin{array}{l}\text { Cover and } \\
\text { bar spacing }\end{array}$} & \multicolumn{2}{|c|}{$\begin{array}{c}\text { Stirrup } \\
\text { at splice }\end{array}$} & \multirow{2}{*}{$\begin{array}{l}\frac{\left(c+K_{t r}\right)}{d_{b}} \\
(\text { Eq. (1)) }\end{array}$} & \multirow{2}{*}{$\begin{array}{c}\text { Design } \\
\text { splice } \\
\text { length } \\
1.3 l_{d} \\
(\mathrm{~mm})\end{array}$} & \multirow{2}{*}{$\begin{array}{l}\text { Ratio of } \\
\text { actual } \\
\text { splice } \\
\text { length } \\
\frac{l_{s}}{1.3 l_{d}}\end{array}$} & \multirow{2}{*}{$\begin{array}{c}\text { Flexural } \\
\text { re-bar } \\
\text { ratio } \\
\rho \\
(\%)\end{array}$} \\
\hline & & & & & & & $\begin{array}{l}c_{b}^{(1)} \\
(\mathrm{mm})\end{array}$ & $\begin{array}{l}c_{S o}^{(1)} \\
(\mathrm{mm})\end{array}$ & $\begin{array}{c}c_{s i}^{(1)} \\
(\mathrm{mm})\end{array}$ & $\begin{array}{l}K_{t r} \\
\text { Eq. } \\
(2)\end{array}$ & $\begin{array}{c}\text { Spacing } \\
s \\
(\mathrm{~mm})\end{array}$ & & & & \\
\hline SB1 & 24 & D22 & Beam & 300 & 450 & 51 & 40 & 40 & 66 & - & - & 2.32 & 1360 & 0.98 & 0.65 \\
\hline SB2 & 60 & D22 & Beam & 300 & 450 & 51 & 40 & 40 & 66 & - & - & 2.32 & 860 & 0.98 & 0.65 \\
\hline SB3 & 24 & D22 & Beam & 300 & 450 & 51 & 40 & 40 & 66 & 10.7 & 250 & 2.80 & 1261 & 0.84 & 0.65 \\
\hline SB4 & 24 & D13 & Beam & 250 & 350 & 46.5 & 40 & 40 & 59 & - & - & 3.58 & 596 & 0.60 & 0.34 \\
\hline SB5 & 24 & D13 & Beam & 250 & 350 & 26.5 & 20 & 40 & 59 & - & - & 2.04 & 731 & 1.02 & 0.32 \\
\hline SB6 & 24 & D13 & Slab & 450 & 200 & 46.5 & 40 & 40 & 41 & - & - & 3.58 & 596 & 0.60 & 0.37 \\
\hline SB7 & 24 & D13 & Slab & 450 & 200 & 26.5 & 20 & 20 & 41 & - & - & 2.04 & 731 & 1.02 & 0.33 \\
\hline SB8 & 24 & D22 & Beam & 300 & 450 & 61 & 50 & 50 & 56 & - & - & 2.77 & 1261 & 1.00 & 0.66 \\
\hline SB9 & 24 & D22 & Beam & 300 & 450 & 61 & 50 & 50 & 56 & 10.6 & 250 & 3.26 & 1261 & 1.00 & 0.66 \\
\hline SB10 & 60 & D32 & Beam & 400 & 600 & 66 & 50 & 50 & 86 & - & - & 2.06 & 1406 & 1.00 & 0.77 \\
\hline SB11 & 28 & D32 & Beam & 400 & 600 & 66 & 50 & 50 & 86 & 14.0 & 190 & 2.50 & 1699 & 1.00 & 0.77 \\
\hline SB12 & 28 & D32 & Beam & 400 & 600 & 66 & 50 & 50 & 86 & 22.1 & 120 & 2.75 & 1699 & 1.00 & 0.77 \\
\hline
\end{tabular}

${ }^{(1)}$ See A-A section in Figs. 3 and 4

${ }^{(2)} c=\min$ of $\left[\left(c_{b}+d_{b} / 2\right),\left(c_{s i}+d_{b} / 2\right),\left(c_{s o}+d_{b} / 2\right)\right]$

전단 파괴가 발생하지 않도록 전단력이 작용하는 구간에 $s_{2}$ 간격으로 $\mathrm{SD} 400 / \mathrm{D} 10$ 의 횡보강 철근을 배치하였다(Fig.

2). $\mathrm{SB} 1 \sim \mathrm{SB} 5$ 와 $\mathrm{SB} 8, \mathrm{SB} 9$ 는 $s_{2}$ 가 $100 \mathrm{~mm}$ 이고, $\mathrm{SB} 10 \sim \mathrm{SB} 12$ 는 $s_{2}$ 가 $50 \mathrm{~mm}$ 이다. 슬래브 실험체는 예상 전단력이 작 기 때문에 횡보강 철근을 사용하지 않았다.

모든 실험체는 Fig. 2와 같이 실험체 끝에서 $250 \mathrm{~mm}$ 떨어진 지점을 힌지로 단순 지지하였으며, 하중 재하 위 치는 이음 성능에 영향이 발생하지 않도록 겹침 이음의 끝에서 $300 \mathrm{~mm}$ 이상 떨어진 지점으로 계획하였다. 변위 측정은 변위계(LVDT)를 사용하여 실험체 가운데 지점의 처짐을 측정하였으며, 변형률 게이지는 모든 주철근의 이 음길이 외부에서 겹침 이음 구간에 최대한 가깝도록 설 치하였다.

12 개의 겹침 이음 실험체 상세와 설계변수를 Fig. 2 와 Table 1 에 나타내었다. 콘크리트 설계강도는 $30 \mathrm{MPa}$ 이 하인 $24 \mathrm{MPa}, 28 \mathrm{MPa}$ 의 보통 강도 콘크리트 또는 $60 \mathrm{MPa}$ 의 고강도 콘크리트를 사용하였으며, 철근은 $\mathrm{D} 13, \mathrm{D} 22$, $\mathrm{D} 32$ 을 사용하였다. 슬래브 실험체는 직경 D13에 대해서 만 계획하였다.

Table 1 의 철근 간격 또는 피복 두께와 관련된 치수 $c$ 와 횡방향 철근지수 $K_{t r}$ (식 (2))은 겹침 이음에 대한 구속수 준을 나타내는 $\left(c+K_{t r}\right) / d_{b}$ (식 (1))을 결정한다. ACI408R$03^{4}$ 에 따르면 현행 설계기준 ${ }^{1)}$ 의 겹침 이음 관련 규정은 Fig. 4와 같은 쪼개짐 파괴에 기반하여 만들어졌으므로 뽑힘 파괴가 발생할 경우는 적절한 철근 응력의 예측이 어렵다. 뽑힘 파괴는 콘크리트 피복과 횡보강 철근에 의 한 구속 효과가 크고 부착 길이가 짧을 때 발생하기 때 문에 현행 설계기준 ${ }^{1)}$ 에서는 $\left(c+K_{t r}\right) / d_{b}$ 가 2.5 를 초과하

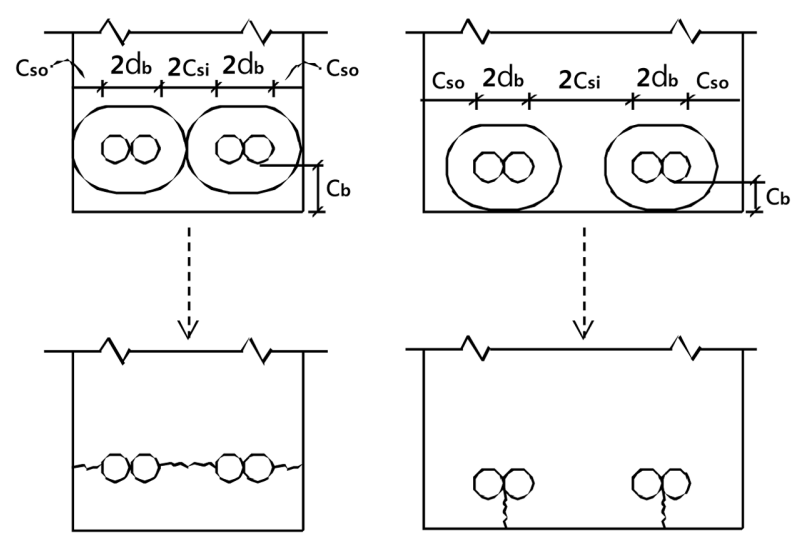

Fig. 4 Splitting failure of spliced bars

는 경우 뽑힘 파괴를 고려하여 2.5 를 적용하도록 규정하 고 있다. $c$ 는 Table 1 의 $c_{b}, c_{s o}, c_{s i}$ 에 의하여 결정되며, 그 정의는 Figs. 2와 4에서 나타내었다. 현행 설계기준에에서 $c$ 는 철근 중심에서 콘크리트 표면까지의 거리인 $\left(c_{b}+d_{b} / 2\right)$, $\left(c_{s o}+d_{b} / 2\right)$ 와 겹침 이음 철근 중심간 거리의 $1 / 2$ 인 $\left(c_{s i}+\right.$ $\left.d_{b} / 2\right)$ 중 가장 작은 값으로 결정되며, 이 실험에서는 모든 실험체의 $c$ 가 하부 피복 두께에 의하여 $\left(c_{b}+d_{b} / 2\right)$ 로 결정 되도록 계획하였다.

Table 1 의 $l_{s} / 1.3 l_{d}$ 는 현행 $\mathrm{KCI}$ 설계기준 ${ }^{1)}$ 에 의해 산정된 $\mathrm{B}$ 급 겹침 이음 길이 $1.3 l_{d}$ 에 대한 실제 겹침 이음 길이 $l_{s}$ 의 비율이며, $\rho$ 는 겹침 이음한 주인장 철근의 철근비이다.

$\mathrm{SD} 600 / \mathrm{D} 13$ 은 보(SB4, SB5)와 슬래브(SB6, SB7)의 4개의 실험체에 사용되었다. 현행 설계기준 ${ }^{1}$ 에서 규정하는 슬래 브와 보의 최소 피복 두께는 $20 \mathrm{~mm}$ 와 $40 \mathrm{~mm}$ 이므로 SB5 와 $\mathrm{SB} 7$ 은 $c_{b}=20 \mathrm{~mm}$ 로 설계하였으며, $\mathrm{SB} 4$ 와 $\mathrm{SB} 6$ 은 $c_{b}=$ 
$40 \mathrm{~mm}$ 로 계획하였다. D13의 겹침 이음은 횡보강 철근 없이 사용되는 경우가 많기 때문에 $\mathrm{SB} 4 \sim \mathrm{SB} 7$ 은 횡보강 철 근을 배치하지 않았다. $c_{b}=40 \mathrm{~mm}$ 인 경우(SB4, SB6)는 $(c+$ $\left.K_{t r}\right) / d_{b}$ 가 3.58 로 2.5 를 크게 상회하고 실제 겹침 이음 길 이가 $\mathrm{B}$ 급 이음 길이의 $60 \%$ 로 설계하였기 때문에 뽑힘 파 괴가 발생할 가능성이 높다. 콘크리트 설계강도는 공통적 으로 $24 \mathrm{MPa}$ 을 사용하였다.

$\mathrm{SD} 600 / \mathrm{D} 22$ 는 $\mathrm{SB} 1, \mathrm{SB} 2, \mathrm{SB} 3, \mathrm{SB} 8, \mathrm{SB} 9$ 5개의 보 실험 체에 사용되었다. $\mathrm{SB} 1, \mathrm{SB} 2, \mathrm{SB} 3$ 는 $c_{b}$ 가 $40 \mathrm{~mm}$ 이고, $\mathrm{SB} 8$ 과 $\mathrm{SB} 9$ 는 $c_{b}$ 가 $50 \mathrm{~mm}$ 이다. $\mathrm{SB} 1$ 은 보통 강도 콘크리트 $\left(f_{c k}=24 \mathrm{MPa}\right)$ 에 횡보강 철근을 사용하지 않고 현행 설 계기준 ${ }^{1)}$ 에서 규정하는 보의 최소 피복 두께인 $40 \mathrm{~mm}$ 를 적용하였다. $\mathrm{SB} 2$ 와 $\mathrm{SB} 3$ 는 $\mathrm{SB} 1$ 과 유사하지만 $\mathrm{SB} 2$ 는 고강 도 콘크리트 $\left(f_{c k}=60 \mathrm{MPa}\right)$ 를 사용하였으며, $\mathrm{SB} 3$ 는 $\mathrm{SD} 400 /$ $\mathrm{D} 10$ 의 횡보강 철근을 겹침 이음 구간에 $250 \mathrm{~mm}$ 간격으로 배치하였다. $\mathrm{SB} 1$ 과 $\mathrm{SB} 2$ 는 $\left(c+K_{t r}\right) / d_{b}=2.32$ 이며, $\mathrm{SB} 3$ 는 실제 겹침 이음 길이가 $\mathrm{B}$ 급 이음 길이의 $84 \%$ 이고 $\left(c+K_{t r}\right)$ $/ d_{b}=2.8$ 이다. $\mathrm{SB} 8$ 은 $\mathrm{SB} 1$ 과 유사하며 $c_{b}$ 가 $50 \mathrm{~mm}$ 로 증가 되었다. SB9는 겹침 이음 구간에 횡보강 철근을 $250 \mathrm{~mm}$ 간격으로 배치하였으며, 다른 설계 조건은 $\mathrm{SB} 8$ 과 동일 하다. $\left(c+K_{t r}\right) / d_{b}$ 는 $\mathrm{SB} 8$ 이 2.77이며, $\mathrm{SB} 9$ 는 3.26 이다.

$\mathrm{SD} 600 / \mathrm{D} 32$ 는 $\mathrm{SB} 10, \mathrm{SB} 11, \mathrm{SB} 12$ 3개의 실험체에 사용 되었으며, 모든 실험체의 $c_{b}$ 는 $50 \mathrm{~mm}$ 이다. $\mathrm{SB} 10$ 은 횡보강 철근 없이 고강도 콘크리트 $\left(f_{c k}=60 \mathrm{MPa}\right)$ 를 사용하여 설 계하였으며, $\left(c+K_{t r}\right) / d_{b}$ 는 2.06이다. $\mathrm{SB} 11$ 은 보통 강도 콘크리트 $\left(f_{c k}=24 \mathrm{MPa}\right)$ 에 $\left(c+K_{t r}\right) / d_{b}$ 가 2.5 가 되도록 횡보 강 철근 간격을 $190 \mathrm{~mm}$ 로 배치하였으며, $\mathrm{SB} 12$ 는 횡보강 철근 간격을 $120 \mathrm{~mm}$ 로 배치하여 $\left(c+K_{t r}\right) / d_{b}$ 는 2.75이다.

Table 1에서 SB8과 SB9 또는 SB11과 SB12는 $\left(c+K_{t r}\right)$ / $d_{b}$ 가 다르지만 현행 설계기준 ${ }^{1)}$ 에 의한 $\mathrm{B}$ 급 이음길이가
같은 것을 확인할 수 있으며, 그 이유는 겹침 이음 길이 계산에서 $\left(c+K_{t r}\right) / d_{b}$ 가 2.5 이상일 경우는 동일하게 2.5 를 적용하기 때문이다. $\left(c+K_{t r}\right) / d_{b}$ 가 2.5 를 초과할 때 이 음 길이는 동일하지만 철근의 구속 수준은 증가하기 때 문에 상대적으로 안전측의 설계가 이루어지는 경향이 있다.

Table 2에서는 실험체 제작 후 측정한 실제 변수값을 나타내었다. Table 2의 실제 변수값은 콘크리트 압축강 도와 철근 항복 응력의 측정값, 실제 콘크리트 피복 두 께에 의한 $c$ 값이며, 실제 피복 두께는 Table 1 의 계획보 다 약간 작은 경향을 보였다. $1.3 l_{d}^{\prime}$ 는 실제 콘크리트 강 도와 실제 $c$ 값을 반영하여 $600 \mathrm{MPa}$ 의 철근 응력이 기대 되는 현행 설계기준 ${ }^{1}{ }^{\circ}$ 의 $\mathrm{B}$ 급 이음 길이이다.

\section{5. 실험 결과}

모든 실험 결과는 Table 2에서 요약하였다. 실험 결과 의 분석을 위하여 실제 콘크리트 압축강도와 실제 $c$ 값을 반영하여 실제 겹침 이음 길이 $l_{s}$ 에 대한 현행 $\mathrm{KCI}$ 설계기 준, ${ }^{1)}$ ACI408R-03, ${ }^{4}$ Eurocode $2^{9}$ 의 예측 응력 $\left(f_{s, c a l}\right)$ 을 계산 하였다. 실험 결과는 각 실험체의 파괴 모드와 실제 철근 응력으로 나타내었으며, 실제 철근 응력은 변형률 게이지 를 이용하여 측정하였다. 현행 설계기준 ${ }^{1)}$ 의 적용성은 $\mathrm{KCI}$ 설계기준 ${ }^{1)}$ 의 예측 철근 응력에 대한 실제 철근 응력의 비율 $\left(f_{s, t e s t} / f_{s, K C I}\right)$ 에 기반하여 평가하였다. 각 실험체의 예 측 휨강도와 예측 전단강도는 실제 재료 강도를 기반으 로 계산하였다.

\section{1 파괴 모드}

각 실험체의 파괴 모드는 Table 2에 나타내었으며 그

Table 2 Summary of actual properties and test results of specimens

\begin{tabular}{|c|c|c|c|c|c|c|c|c|c|c|c|c|c|c|}
\hline \multirow{2}{*}{$\begin{array}{l}\text { Specimen } \\
\text { ID }\end{array}$} & \multirow{2}{*}{$\begin{array}{c}\text { Measured } \\
\text { concrete } \\
\text { strength } \\
f_{c u} \\
(\mathrm{MPa})\end{array}$} & \multirow{2}{*}{$\begin{array}{c}\text { Re-bars } \\
\text { diameter } \\
d_{b}\end{array}$} & \multirow{2}{*}{$\begin{array}{c}\text { Measured } \\
f_{y} \\
(\mathrm{MPa})\end{array}$} & \multirow{2}{*}{$\begin{array}{c}\text { Measured } \\
c \\
(\mathrm{~mm})\end{array}$} & \multirow{2}{*}{$\begin{array}{l}\text { Splice }^{(1)} \\
\text { length } \\
\left(l_{s} / 1.3 l_{d}^{\prime}\right)\end{array}$} & \multicolumn{3}{|c|}{$\begin{array}{c}\text { Calculated stress } f_{s, c a l} \\
(\mathrm{MPa})\end{array}$} & \multirow{2}{*}{\begin{tabular}{|c} 
Developed \\
stress \\
$f_{s, t e s t}$ \\
$(\mathrm{MPa})$
\end{tabular}} & \multirow{2}{*}{$\frac{f_{s, t e s t}}{f_{s, K C I}}$} & \multirow{2}{*}{$\frac{c+K_{t r}}{d_{b}}$} & \multicolumn{2}{|c|}{$\begin{array}{c}\text { Estimated } \\
\text { strength } \\
\text { of specimens }\end{array}$} & \multirow{2}{*}{$\begin{array}{l}\text { Failure } \\
\text { mode }\end{array}$} \\
\hline & & & & & & $\begin{array}{c}\mathrm{KCI} \\
f_{s, K C I} \\
(\mathrm{ACI} 318)\end{array}$ & $\begin{array}{c}\mathrm{ACI} \\
408 \mathrm{R}-03\end{array}$ & $\begin{array}{c}\text { Eurocode } \\
2\end{array}$ & & & & $\begin{array}{c}\text { Flexural } \\
(\mathrm{kN}-\mathrm{m})\end{array}$ & $\begin{array}{l}\text { Shear } \\
(\mathrm{kN})\end{array}$ & \\
\hline SB1 & 24.7 & D22 & 720 & 51 & 1.00 & 597.6 & 574.1 & 566.3 & 557.2 & 0.93 & 2.32 & 198.8 & 552.4 & Splitting \\
\hline SB2 & 51 & D22 & 720 & 51 & 0.90 & 542.6 & 481.2 & 580.3 & 584.5 & 1.08 & 2.32 & 210.3 & 586.8 & Splitting \\
\hline SB3 & 24.7 & D22 & 720 & 51 & 0.85 & 508.3 & 530.5 & 447 & 559.3 & 1.10 & 2.8 & 198.8 & 552.4 & Splitting \\
\hline SB4 & 24.7 & D13 & 650 & 46.5 & 0.63 & 380.9 & 447.5 & 335.8 & 621.1 & 1.63 & 3.58 & 48.7 & 407.6 & Pullout \\
\hline SB5 & 24.7 & D13 & 650 & 26.5 & 1.03 & 620.8 & 544.3 & 510.8 & 650 (yield) & 1.05 & 2.04 & 52.1 & 434.5 & Yielding \\
\hline SB6 & 24.7 & D13 & 650 & 46.5 & 0.63 & 380.9 & 447.5 & 335.8 & 650 (yield) & 1.71 & 3.58 & 45.9 & 231.6 & Splitting \\
\hline SB7 & 24.7 & D13 & 650 & 26.5 & 1.03 & 620.8 & 494.8 & 510.8 & 650 (yield) & 1.05 & 2.04 & 52.6 & 261.8 & Yielding \\
\hline SB8 & 29.8 & D22 & 720 & 56 & 1.11 & 668.1 & 626.8 & 630.7 & 658.7 & 0.99 & 2.55 & 199.6 & 555.1 & Splitting \\
\hline SB9 & 29.8 & D22 & 720 & 56 & 1.11 & 668.1 & 702.9 & 637.1 & 720 (yield) & 1.08 & 3.03 & 199.6 & 555.1 & Yielding \\
\hline SB10 & 55.3 & D32 & 700 & 56 & 0.82 & 490.1 & 454.3 & 641.9 & 549 & 1.12 & 1.75 & 589.0 & 887.7 & Splitting \\
\hline SB11 & 33.0 & D32 & 700 & 63 & 1.05 & 628.6 & 583.8 & 567.9 & 700 (yield) & 1.11 & 2.41 & 559.2 & 815.7 & Splitting \\
\hline SB12 & 33.0 & D32 & 700 & 61 & 1.09 & 652.1 & 628.1 & 579.7 & 700 (yield) & 1.07 & 2.60 & 561.4 & 818.7 & Yielding \\
\hline
\end{tabular}

(1) $1.3 l_{d}^{\prime}$ is class B splice length calculated by 'measured $f_{c u}$ ' and 'measured c' 


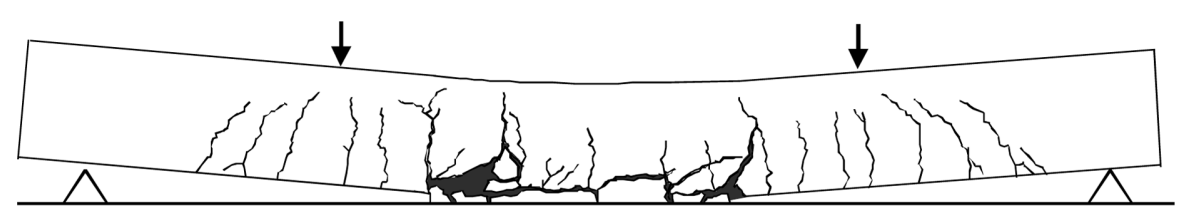

(a) Splitting failure of unconfined splices (SB1)

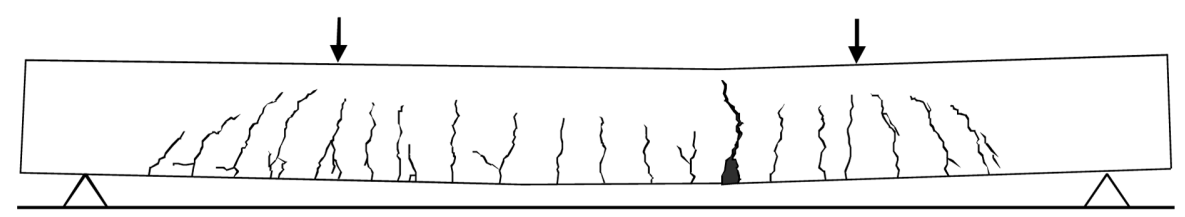

(b) Splitting failure of confined splices (SB3)

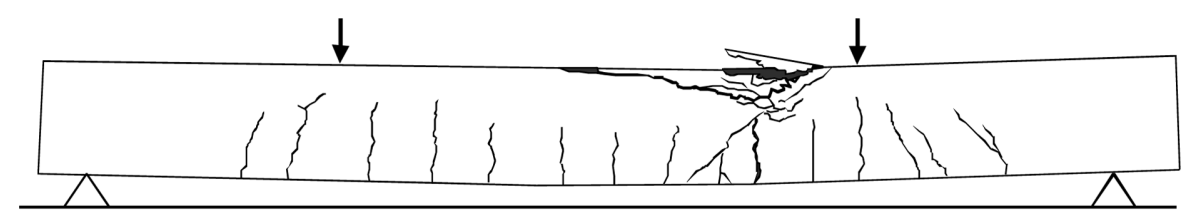

(c) Flexure failure after yielding (SB9)

Fig. 5 Failure modes of test specimens at the end of test

대표적인 파괴 모드는 Fig. 5에 나타내었다. 횡보강 철근 없이 $\mathrm{D} 22$ 철근을 사용한 $\mathrm{SB} 1, \mathrm{SB} 2, \mathrm{SB}$ 과 $\mathrm{D} 32$ 철근을 사용한 $\mathrm{SB} 10$ 은 취성적인 쪼개짐 파괴 모드를 보였다(Fig. 5(a)). 반면에 횡보강 철근 없이 작은 직경의 D13 철근을 겹침 이음한 $\mathrm{SB} 5, \mathrm{SB} 6, \mathrm{SB} 7$ 은 항복 후 연성 거동을 보이 거나 휨 변형이 많이 일어난 후에 쪼개짐 파괴가 발생하 였다. $\mathrm{D} 13$ 철근을 겹침 이음한 실험체 중 $\mathrm{SB} 4$ 는 $\mathrm{B}$ 급 이 음 길이의 $60 \%$ 정도로 겹침 이음하였으며, $\left(c+K_{t r}\right) / d_{b}$ 가 3.58 로 2.5 를 크게 상회하기 때문에 유일하게 뽑힘 파괴 가 발생하였다.

겹침 이음 구간에 횡보강 철근을 배치한 실험체 중 쪼 개짐 파괴가 발생한 $\mathrm{SB} 3(\mathrm{D} 22)$ 와 $\mathrm{SB} 11(\mathrm{D} 32)$ 은 횡보강 철 근을 사용하지 않은 실험체에 비하여 변형 능력이 우수 하고, 취성적인 쪼개짐 파괴가 발생하기 전에 휨 변형이 많이 발생하였다(Fig. 5(b)). 이 결과를 통하여 횡보강 철 근을 사용한 실험체의 파괴 모드는 횡보강 철근을 사용 하지 않은 실험체에 비하여 훨씬 연성적임을 확인하였다.

$\mathrm{D} 22$ 와 $\mathrm{D} 32$ 를 사용하고 횡보강 철근을 배치하였으며 실제 $c_{b}$ 가 $45 \mathrm{~mm}$ 인 $\mathrm{SB} 9(\mathrm{D} 22)$ 와 $\mathrm{SB} 12(\mathrm{D} 32)$ 는 주인장 철 근이 먼저 항복하고, 콘크리트 압축대에서 파괴가 일어 나는 휨연성 거동을 보였다(Fig. 5(c)).

이 실험의 파괴 모드를 종합하여 분석한 결과 SD600 철근의 겹침 이음은 철근 직경이 작을수록, 횡보강 철근 이 많을수록, 피복 두께가 클수록 휨연성 거동(Fig. 5(c)) 을 보이며, 반대의 경우에 쪼개짐 파괴(Fig. 5(a))가 발생 하는 것으로 나타났다.

\section{2 모멘트-변위 관계}

Fig. 6은 SD600철근의 직경에 따라서 겹침 이음 구간 에 작용하는 최대 모멘트와 실험체 경간 중앙 변위의 관 계를 나타낸 것이며, 비교를 위하여 휨 항복이 발생한
실험체 $(\mathrm{SB} 5, \mathrm{SB} 9, \mathrm{SB} 12)$ 단면의 예상 휨 극한 강도를 표 시하였다. 각 실험체의 예상 휨 극한 강도는 실제 콘크 리트 압축강도와 주인장 철근의 실제 항복 강도를 기반 으로 계산하였다.

Fig. 6(a)는 SD600/D13를 사용한 겹침 이음의 실험 결과 를 나타내었다. 측정된 $c_{b}$ 가 $20 \mathrm{~mm}$ 이고 $\mathrm{B}$ 급 이음 길이를 만족하도록 설계한 $\mathrm{SB} 5$ 와 $\mathrm{SB}$ 7에서 휨항복이 발생하였 다. $\left(c+K_{t r}\right) / d_{b}=3.58$ 로 콘크리트 피복에 의한 구속이 크 고 이음 길이가 짧은 $\mathrm{SB} 4$ 와 $\mathrm{SB}$ 6에서는 실험체가 항복 하지는 않았지만 설계기준 항복 강도 $600 \mathrm{MPa}$ 이상의 철근 응력이 발현된 후 파괴되었다.

Fig. 6(b)는 SD600/D22를 사용한 겹침 이음의 실험 결 과를 나타내었다. 측정된 $c_{b}$ 가 $40 \mathrm{~mm}$ 로 동일한 $\mathrm{SB} 1, \mathrm{SB} 2$, $\mathrm{SB} 3$ 에서 고강도 콘크리트와 횡보강 철근의 영향을 확인 할 수 있다. 고강도 콘크리트를 사용한 $\mathrm{SB} 2$ 는 부재의 강 도가 보통 강도 콘크리트를 사용한 $\mathrm{SB} 1$ 보다 크게 나타났 다. 횡보강 철근을 배치한 $\mathrm{SB} 3$ 는 $\mathrm{B}$ 급 이음 길이의 0.8 배에 해당하는 겹침 이음 길이만을 확보하였음에도 불구하고 부 재 강도가 세 실험체 중에서 가장 크게 나타났다. SB8과 $\mathrm{SB} 9$ 는 측정된 $c_{b}$ 와 겹침 이음 길이가 $45 \mathrm{~mm}$ 와 $1,261 \mathrm{~mm}$ 로 동일하지만 횡보강 철근을 사용하지 않은 $\mathrm{SB} 8$ 보다 횡보강 철근을 배치한 $\mathrm{SB} 9$ 의 강도가 $15 \%$ 크게 나타났 다. 또한 $\mathrm{SB} 8$ 은 취성적으로 쪼개짐 파괴가 발생하였으 며, SB9는 휨항복 거동하여 SB9의 변형 능력이 훨씬 우 수한 결과를 확인하였다.

Fig. 6(c)는 SD600/D32를 사용한 겹침 이음의 실험 결 과를 나타내었다. 횡보강 철근을 배치하였으며 겹침 이 음 길이가 같은 $\mathrm{SB} 11$ 과 $\mathrm{SB} 12$ 를 통하여 횡보강 철근 간 격의 영향을 확인할 수 있다. 겹침 이음 구간에 배치한 횡보강 철근 간격이 $120 \mathrm{~mm}$ 인 $\mathrm{SB} 12$ 는 횡보강 철근 간격 이 $190 \mathrm{~mm}$ 인 SB11과 부재의 강도는 비슷하지만 SB12가 더 우수한 변형 능력을 나타내었다. 


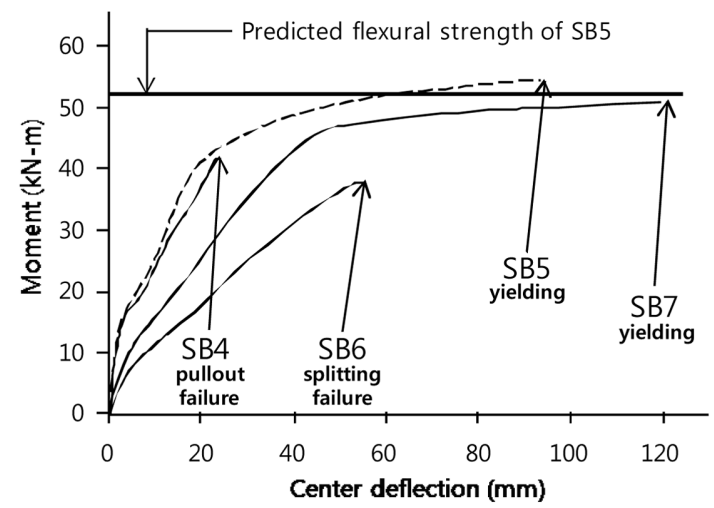

(a) D13 re-bars

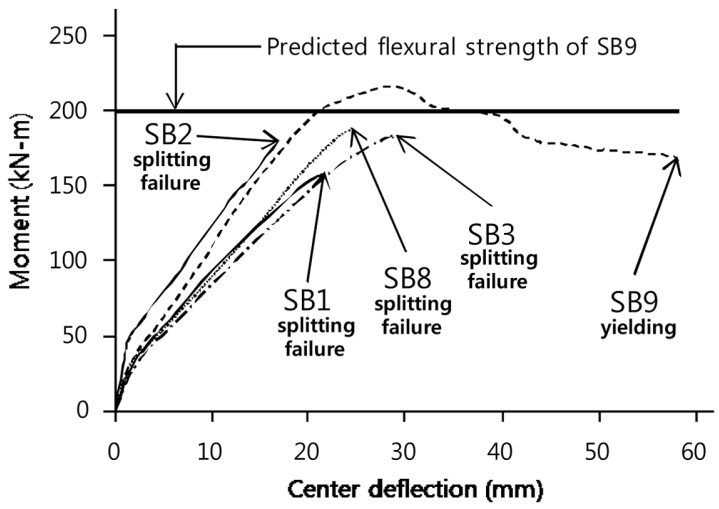

(b) D22 re-bars

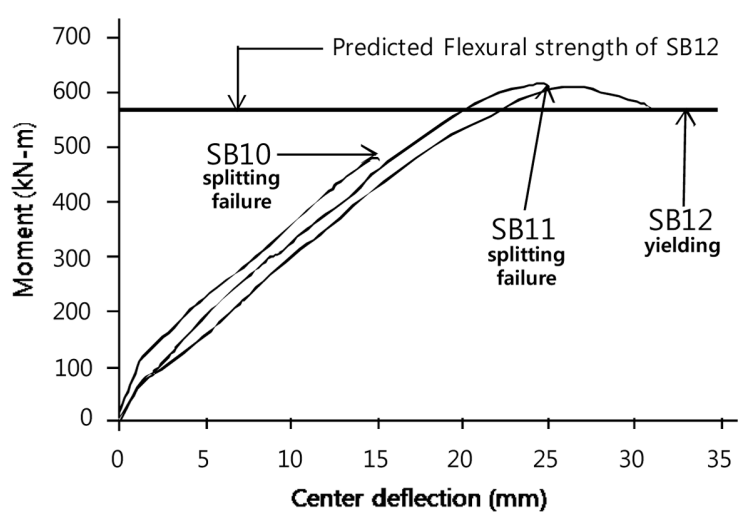

(c) D32 re-bars

Fig. 6 Center moment-deflection relationship of specimens

\section{3 철근 응력}

$\mathrm{KCI}$ 설계기준 ${ }^{1)}($ 식 (1))에 의하여 예측되는 겹침 이음 철 근의 응력 $f_{s, K C I}$ 와 실험에서 실제로 발현된 철근 응력 $f_{s, t e s t}$ 를 비교하였다.

$$
\begin{aligned}
& l_{d}=\frac{0.9 d_{b} f_{s}}{\sqrt{f_{c k}}} \frac{\gamma}{\left(\frac{c+K_{t r}}{d_{b}}\right)} \\
& K_{t r}=\frac{A_{t r} f_{y t}}{10.7 s n}
\end{aligned}
$$

설계기준에서는 $f_{s}$ 를 철근의 설계기준 항복 강도 $\left(f_{y}\right)$ 로 치 환하여 겹침 이음 길이를 산정한다. 이 실험은 에폭시도

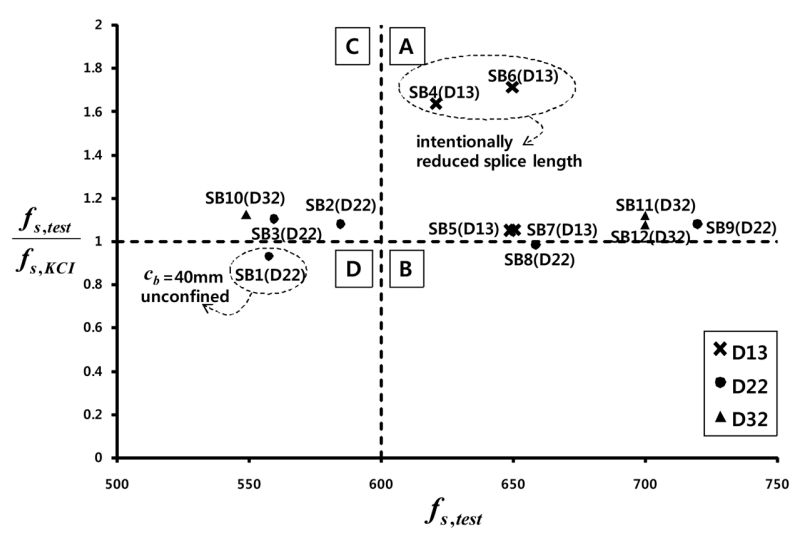

Fig. 7 Re-bar stress ratio between test results and the predictions by $\mathrm{KCl} \mathrm{B}$-calss splice

막, 경량 콘크리트를 사용하지 않았으며, 콘크리트 타설 깊이가 영향을 미치지 않으므로 관련 계수를 생략하였다.

식 (1), (2)에서 각 계수의 정의는 $\mathrm{KCI}$ 콘크리트 설계 기준 ${ }^{1}$ 과 동일하다. $\mathrm{B}$ 급 이음의 경우 $1.3 l_{d}$ 를 사용한다.

$\mathrm{KCI}$ 설계기준 ${ }^{1)}($ 식 $(1))$ 에 의한 예측 철근 응력 $\left(f_{s, K C I}\right)$ 은 Table 2의 실제 변수값을 식 (3)에 적용하여 계산하였다.

$$
f_{s, K C I}=\frac{l_{s}}{1.3 \gamma} \frac{\sqrt{f_{c u}}}{0.9 d_{b}}\left\{\frac{\left(c_{b}+\frac{d_{b}}{2}\right)+K_{t r}}{d_{b}}\right\}
$$

식 (3)은 현행 설계기준 ${ }^{1)}$ 의 $\mathrm{B}$ 급 이음길이 설계식을 철근 응력 $f_{s}$ 에 대하여 정리한 것이다. $f_{c u}$ 는 실험 당일 측정한 콘크리트 압축강도이며 실제 $c$ 는 실험 후 측정한 $c_{b}$ 에 $d_{b} / 2$ 를 더한 값이다.

예측 철근 응력 $f_{s, K C I}$ 에 대한 발현 철근 응력 $f_{s, t e s t}$ 의 비 율 $\left(f_{s, t e s t} / f_{s, K C I}\right)$ 과 분포를 Table 2와 Fig. 7에 나타내었다. 겹침 이음 철근이 항복한 경우에는 철근의 발현 응력을 실제 항복 응력으로 나타내었다. Fig. 7에 나타난 바와 같 이 $\mathrm{SB} 1(\mathrm{D} 22)$ 과 $\mathrm{SB} 8(\mathrm{D} 22)$ 을 제외한 모든 실험체의 발현 철근 응력은 현행 설계기준에 의한 예측 철근 응력을 초 과하였다. 다만 $\mathrm{SB} 2(\mathrm{D} 22), \mathrm{SB} 3(\mathrm{D} 22), \mathrm{SB} 10(\mathrm{D} 32)$ 는 $\mathrm{B}$ 급 이음길이 $1.3 l_{d}^{\prime}$ 보다 겹침 이음 길이 $l_{s}$ 가 짧기 때문에 철 근의 발현 응력이 설계기준 항복 강도 $600 \mathrm{MPa}$ 에 도달 하지 못하였다.

\section{6. $\mathrm{KCl}$ 설계기준 적용성 검토}

Fig. 7에서 가로축의 실제 철근 응력 $f_{\text {s,test }}$ 가 $600 \mathrm{MPa}$ 이 상이고 세로축의 발현 응력 대 예측 응력 비 $f_{s, t e s t} / f_{s, K C I}$ 가 1 이상인 $\mathrm{A}$ 영역은 $\mathrm{SD} 600$ 철근의 겹침 이음 설계에 현행 설계기준 ${ }^{1}$ 을 적용하여도 안전하다고 판단되는 경우이다. $f_{s, t e s t}$ 가 $600 \mathrm{MPa}$ 미만이고 $f_{s, t e s t} / f_{s, K C P}$ 가 1 이상인 C영역 에 있는 실험체들은 현행 설계기준 ${ }^{1)}$ 을 적용하였을 때 안 전할 가능성이 높지만 확실한 검증이 필요한 경우이다. $f_{s, t e s t} / f_{s, K C I}$ 가 1 이하인 영역인 $\mathrm{B}, \mathrm{D}$ 에 속한 실험체는 현 
행 설계기준 ${ }^{1)}$ 을 적용하였을 때 안전하지 못한 경우이다.

$\mathrm{D} 13$ 에 대해서는 $c_{b}=20 \mathrm{~mm}$ 이상의 모든 실험체가 Fig. 7 의 $\mathrm{A}$ 영역에 속한다. 따라서 현행 설계기준 ${ }^{1)}$ 은 $\mathrm{SD} 600 /$ $\mathrm{D} 13$ 에 대하여 안전측으로 적용할 수 있다.

$\mathrm{D} 22$ 에 대해서는 $c_{b}=40 \mathrm{~mm}$ 이고 횡보강 철근이 없는 경우(SB1) 안전측이 아니며, $c_{b}=45 \mathrm{~mm}$ 이고 횡보강 철근이 없는 경우(SB8) $f_{s, t e s t} / f_{s, K C I}$ 가 0.99로 1 에 가까웠다. $c_{b}=$ $45 \mathrm{~mm}$ 이고 횡보강 철근을 배치한 경우(SB9)는 안전측으 로 나타났다.

$\mathrm{D} 32$ 에 대해서는 $c_{b}=45 \mathrm{~mm}$ 이상이고 횡보강 철근을 배 치한 경우(SB11, SB12) 현행 설계기준 ${ }^{1)}$ 이 안전측이었다.

고강도 콘크리트를 사용한 실험체의 $f_{s, t e s t} / f_{s, K C I}$ 는 $\mathrm{SB} 2$ (D22)가 1.08 이고, $\mathrm{SB} 10(\mathrm{D} 32)$ 가 1.12로 모두 1 이상이었다.

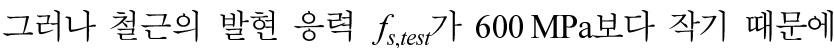
$\left(\mathrm{SB} 2: f_{s, \text { test }}=584.5 \mathrm{MPa}, \mathrm{SB} 10: f_{\text {s,test }}=549 \mathrm{MPa}\right)$ 추가 연구 가 필요하다.

이 연구의 실험 결과를 통하여 직경 $\mathrm{D} 13$ 이하의 철근 은 현행 설계기준 ${ }^{1}$ 을 그대로 적용할 수 있으며, 횡보강 철근을 배치하고 직경 $\mathrm{D} 22$ 이상의 굵은 철근을 사용하 는 경우 또한 현행 설계기준 ${ }^{1)}$ 이 안전측인 것을 확인하 였다. 그러나 굵은 직경의 철근을 횡보강 철근 없이 사 용하는 경우는 현행 설계기준 ${ }^{1)}$ 을 안전측으로 적용할 수 있도록 피복 두께 또는 철근 간격에 관련된 치수인 $c$ 에 대한 제한 사항이 필요한 것으로 판단되었다.

현행 설계기준 ${ }^{1}$ 의 적용성과 설계 변수에 따른 경향성 을 자세히 분석하기 위하여 Seliem 등 $^{7}$ 의 실험 자료를 $\mathrm{B}$ 급 이음에 대하여 분석하였다(기존 연구에서는 $\mathrm{A}$ 급 이 음으로 검증). 횡보강 철근을 배치하지 않은 $\mathrm{MMFX}$ 철근 No.16, No.25, No.36의 실험 결과를 Fig. 8(a)에서 나타내 었다. 철근의 발현 응력은 469 827 MPa이며, 31개 실험 체 중 27 개 실험체의 철근 응력이 $\mathrm{MMFX}$ 철근 응력-변 형률 관계의 선형 구간에서 발현되었으므로 이 연구에서 참고하기에 적합하다. Seliem 등 ${ }^{7)}$ 의 연구에서 실제 콘크 리트 강도는 $28 \sim 70 \mathrm{MPa}$ 이다. $600 \mathrm{MPa}$ 이하의 철근 응 력을 포함한 분석 결과 Fig. 8(a)와 같이 전체 실험체의 $39 \%$ 가 현행 설계기준 ${ }^{1)}$ 에 대하여 안전측이 아니었으나, $c /$
$d_{b}\left(=\left(c+K_{t r}\right) / d_{b}, K_{t r}=0\right) \geq 2.5$ 인 실험체는 10 개 모두 안전 측으로 나타났다. 이 연구에서 실험한 $\mathrm{SB} 1(\mathrm{D} 22)$ 는 $c / d_{b}$ 가 2.32 이고 $f_{s, t e s t} / f_{s, K C I}$ 이 0.93으로 안전측이 아니었으며, SB8 $(\mathrm{D} 22)$ 는 $c / d_{b}$ 가 2.55 이고 $f_{s, t e s t} / f_{s, K C I}$ 가 0.99 로 안전측에 가까웠다. 따라서 이 연구와 Seliem 등ㄱㅇㅢ 실험을 종합한 결과 직경 $\mathrm{D} 16$ 이상의 철근은 $c / d_{b}$ 가 2.5 이상으로 확 보될 경우에 안전한 것으로 나타났다.

횡보강 철근을 배치하여 겹침 이음하는 경우는 이 연 구의 실험 결과 안전측으로 확인되었다 $(\mathrm{SB} 3, \mathrm{SB} 9, \mathrm{SB} 11$, $\mathrm{SB} 12)$. MMFX철근 No.25와 No.36에 대하여 실험한 Seliem 등 $^{7)}$ 의 연구에서 횡보강 철근을 배치한 실험 결과를 $\mathrm{B}$ 급 이음으로 분석하여 Fig. 8(b)에 나타내었다. 철근의 발현 응력은 613 1,069 MPa이었으며, 33개의 실험체 중 1 개를 제외한 모든 실험이 안전측으로 나타났다. 따라서 횡보 강 철근을 배치한 경우에는 $\mathrm{SD} 600$ 철근보다 높은 응력 수준에서 응력-변형률 관계의 비선형성이 발현될 경우에 도 현행 설계기준 ${ }^{1)}$ 을 안전측으로 적용할 수 있음을 확 인하였다. 다만, 현재 시점에서는 안전측의 연성적인 파 괴모드가 발생하기 위한 겹침 이음의 적절한 구속 수준 은 이 연구와 Seliem 등 ${ }^{7)}$ 기존의 실험 자료가 존재하는 $K_{t r} / d_{b} \geq 0.25$ 와 $\left(c+K_{t r}\right) / d_{b} \geq 2.25$ 로 제한할 필요가 있다.

Seliem 등ㄱㅇㅢ 실험 결과에서 고강도 콘크리트의 영향 을 분석하였다. 횡보강 철근을 배치하지 않은 실험체에서 $28 \sim 50 \mathrm{MPa}$ 의 콘크리트를 사용한 경우 $f_{s, t e s t} / f_{s, K C I}$ 의 평균 은 1.17 이며, $50 \sim 70 \mathrm{MPa}$ 의 콘크리트를 사용한 경우 $f_{s, t e s t}$ / $f_{S, K C I}$ 의 평균은 1.03 이었다. 횡보강 철근을 배치한 실험 체에서 $28 \sim 50 \mathrm{MPa}$ 의 콘크리트를 사용한 경우 $f_{s, t e s t} / f_{s, K C I}$ 의 평균은 1.55 이며, $50 \sim 70 \mathrm{MPa}$ 의 콘크리트를 사용한 경 우 $f_{s, t e s t} / f_{s, K C I}$ 의 평균은 1.31 이었다. 분석 결과 더 높은 콘크리트 강도에서 실험체의 안전율이 상대적으로 낮은 경향성을 보였으며, 횡보강 철근을 배치한 Seliem 등ㄱㅇㅢ 실험 결과에서 $68 \mathrm{MPa}$ 의 고강도 콘크리트를 사용한 실 험체가 유일하게 안전측이 아니었다. 따라서 고강도 콘 크리트를 사용한 SD600철근의 겹침 이음에 대한 현행 설계기준 ${ }^{1)}$ 의 적용성은 추가 연구가 필요하다.

Seliem 등 ${ }^{7)}$ 의 실험 결과에서 철근직경의 영향을 분석

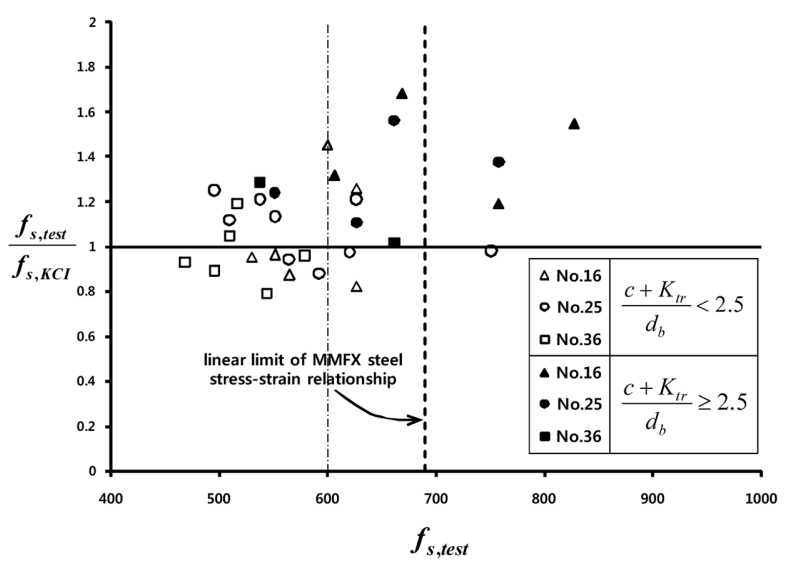

(a) Specimens without lateral re-bars

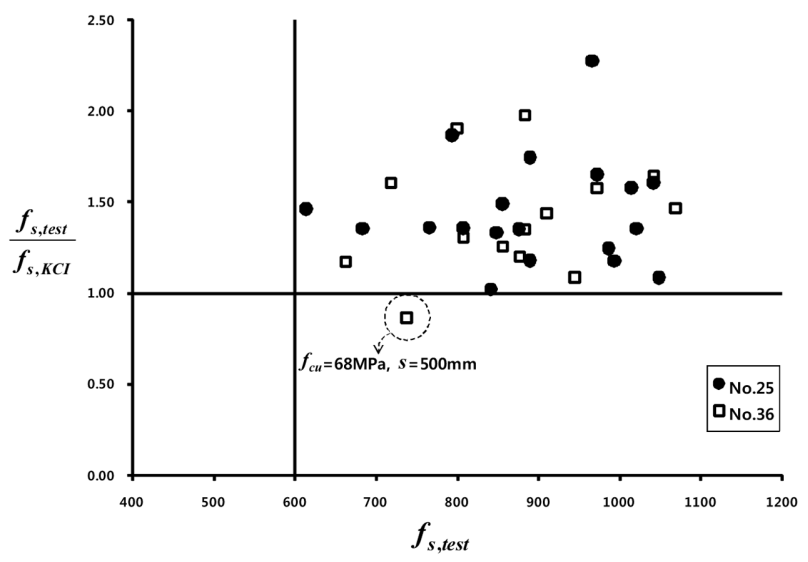

(b) Specimens with lateral re-bars

Fig. 8 Seliem's re-bar stress ratio between test results and the predictions by $\mathrm{KCl} B$-calss splice 
하였다. 횡보강 철근을 배치하지 않은 경우 No. 16, No.25, No.36에서 $f_{s, t e s t} / f_{s, K C I}$ 의 평균이 $1.21,1.15,1.01$ 이고, $c / d_{b}$ 의 평균이 $2.35,2.28,2.20$ 이었다. $c / d_{b}$ 이 커질수록 유리한 경향성이 있으므로 각 철근 직경의 $f_{s, t e s t} / f_{s, K C I}$ 평균을 $c / d_{b}$ 평균으로 나눈 값은 $\mathrm{D} 16, \mathrm{D} 25, \mathrm{D} 36$ 에서 $0.51,0.50,0.46$ 이었다. 따라서 횡보강 철근을 배치하지 않은 경우는 철 근 직경이 커질수록 안전율이 낮아지는 경향을 나타내었 다. 횡보강 철근을 배치한 경우 각 철근 직경의 $f_{s, t e s t} / f_{s, K C I}$ 평균을 $c / d_{b}$ 평균으로 나눈 값은 $\mathrm{D} 25$ 가 0.53 이고, D36 이 0.54 로 비슷한 안전율을 나타내었다. 이러한 경향성 은 $\mathrm{ACI} 408 \mathrm{R}-03^{4)}$ 의 분석 결과와 같으며, 따라서 굵은 직 경의 철근은 횡보강 철근을 배치하는 것이 안전하다.

\section{7. $\mathrm{ACl} 408 \mathrm{R}$ 과 Eurocode의 예측 철근 응력 비교}

$\mathrm{ACI} 408 \mathrm{R}-03^{4)}$ 과 Eurocode $2^{9)}$ 의 겹침 이음 관련 규정은 부록에 나타내었다. ACI408R-03 $3^{4)}$ 과 Eurocode $2^{9)}$ 에 기반 하여 계산한 $f_{s, t e s t} / f_{s, c a l}$ 을 통하여 $\mathrm{KCI}$ 설계기준 ${ }^{1)}\left(\mathrm{ACI} 318^{2)}\right)$ 과 $\mathrm{SD} 600$ 철근에 대한 적용성을 비교하였다. ACI408R$03^{4)}$ 은 $\mathrm{A}$ 급 이음과 $\mathrm{B}$ 급 이음에 대한 구분이 없으며, Seliem 등ㄱㅇㅢ 연구에서 $\mathrm{MMFX}$ 고강도 철근의 항복 강 도 $830 \mathrm{MPa}$ 까지 겹침 이음에 적용할 수 있는 것으로 나타 났다. Eurocode $2^{9)}$ 는 현재 설계기준 항복 강도가 $600 \mathrm{MPa}$ 인 철근까지 적용할 수 있도록 규정되어 있다. 각 설계 기준에 대하여 실험체별로 정리한 $f_{s, t e s t} / f_{s, c a l}$ 을 Fig. 9와 Table 2에 나타내었다. 분석 결과 $\mathrm{KCI}$ 설계기준 ${ }^{1)}(\mathrm{B}$ 급 이 음)의 $f_{s, \text { test }} / f_{s, c a l}$ 평균은 $1.16(\mathrm{COV}=0.21$, 최소 $=0.93)$ 이고, $\mathrm{ACI} 408 \mathrm{R}-03^{4)}$ 에 의한 $f_{s, t e s t} / f_{s, c a l}$ 평균은 $1.18(\mathrm{COV}=0.15$, 최소 $=0.97)$ 이며, Eurocode $2^{9)}$ 에 의한 $f_{s, t e s t} / f_{s, c a l}$ 평균은 $1.25(\mathrm{COV}=0.33$, 최소 $=0.86)$ 이었다.

Eurocode $2^{9)}$ 는 평균이 가장 높지만 변동계수 $(\mathrm{COV})$ 도 가장 크게 나타났다. 대부분의 실험체에서 Eurocode $2^{9)}$ 의 $f_{s, t e s t} / f_{s, c a l}$ 이 가장 높았으나 고강도 콘크리트를 사용하는 경우에 가장 낮은 안전율을 보였다(SB2, SB10). 또한 겹 침 이음의 구속 수준이 높은 경우에 과도하게 높은 안 전율을 보였다(SB4, SB6).

$\mathrm{KCI}$ 설계기준 ${ }^{1)}(\mathrm{B}$ 급 이음)은 평균이 1 에 가장 가깝지 만 $\mathrm{ACI} 408 \mathrm{R}-03^{4)}$ 의 평균과의 차이가 0.02 로 크지 않고, 변동계수는 Eurocode $2^{9)}$ 보다 작았다. ACI408R-03)은 최소

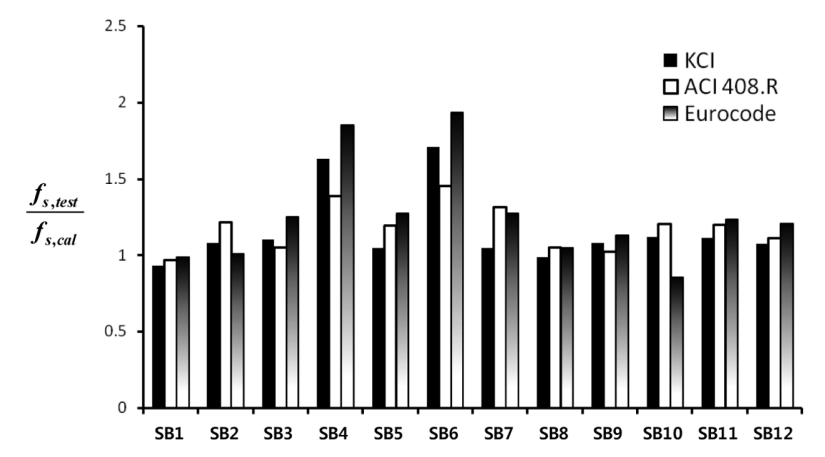

Fig. 9 Developed/calculated values of spliced bars
값이 0.97 로서 안전측에 가깝고, 변동계수가 제일 작기 때 문에 가장 합리적으로 판단되었다. 이러한 경향성은 $\mathrm{ACI}$ 408R-03 ${ }^{2}$ 에서 ACI Committee $408^{3,4)}$ 자료에 기반하여 분 석한 결과와 동일하였다.

이 연구에서 참고한 Seliem 등ㄱㅇㅢ 실험 결과를 현행 설계기준 ${ }^{1)}$ 의 B급 이음과 ACI408R-03 ${ }^{4)}$ 에 대하여 분석하 였다. 횡보강 철근을 사용하지 않은 경우는 $\mathrm{KCI}$ 설계기 준 $^{1)}$ 의 $f_{s, t e s t} / f_{s, c a l}$ 평균이 $1.13(\mathrm{COV}=0.20)$ 이고 최소값이 0.79 이었으며, $c / d_{b}$ 이 2.5 이상인 10 개 실험체의 $f_{s, t e s t} / f_{s, c a l}$ 평균은 $1.33(\mathrm{COV}=0.16)$ 이고 최소값은 1.01 이었다. $\mathrm{ACI}$ $\left.408 \mathrm{R}-03^{4}\right)$ 의 $f_{s, t e s t} / f_{s, c a l}$ 평균은 $1.19(\mathrm{COV}=0.11)$ 이고 최소값 이 0.92 이었으며, 31 개 실험체 중 2 개를 제외한 모든 실 험체가 안전측이었다. 횡보강 철근을 배치한 경우는 $\mathrm{KCI}$ 설계기준 ${ }^{1)}$ 의 $f_{s, t e s t} / f_{s, c a l}$ 평균이 $1.43(\mathrm{COV}=0.21)$ 이고 최 소값이 0.86 이었으며, 33 개 실험체 중 1 개를 제외한 모든 실험체가 안전측이었다. ACI $408 \mathrm{R}-03^{4)}$ 의 $f_{s, t e s t} / f_{s, c a l}$ 평균은 $1.29(\mathrm{COV}=0.10)$ 이고 최소값이 1.03 이었다.

횡보강 철근을 배치하지 않을 경우에는 $\mathrm{KCI}$ 설계기준 ${ }^{1)}$ 은 $c / d_{b}$ 가 2.5 이상인 경우에 안전측이며, $\mathrm{ACI} 408 \mathrm{R}-03^{4)}$ 은 $\mathrm{KCI}$ 설계기준 ${ }^{1)}$ 에 비하여 경제적이고 대부분의 경우 안전측의 설계가 가능하지만 $c / d_{b}$ 가 2 미만이고 No.36 철근을 사용한 2 개의 실험체가 안전측이 아니었다. 횡보 강 철근을 배치할 경우 $\mathrm{KCI}$ 설계기준 ${ }^{1}$ 과 $\mathrm{ACI} 408 \mathrm{R}-03^{4)}$ 은 안전측이었으나, $\mathrm{KCI}$ 설계기준 ${ }^{1)}$ 은 $\mathrm{No} .36$ 을 사용하고 $K_{t r}$ / $d_{b}$ 가 0.15 인 실험체가 안전측이 아니었다. 또한, $\mathrm{KCI}$ 설계 기준 ${ }^{1)}$ 은 변동계수(COV)가 ACI408R-03 ${ }^{4}$ 의 2 배 이상이며, 변수에 따라서 과도하게 높은 안전율을 나타내는 경우가 있으므로 ACI408R-034)이 더 경제적이다.

\section{8. 결 론}

이 연구에서는 $\mathrm{SD} 600$ 철근을 사용한 실물 크기의 $\mathrm{B}$ 급 겹 침 이음 실험을 수행하였으며, $\mathrm{KCI}$ 설계기준, ${ }^{1)} \mathrm{ACI} 408 \mathrm{R}-$ $03,{ }^{4)}$ Eurocode $2^{9}$ 의 설계규정에 대하여 겹침 이음 성능을 평가하였다. 또한 $\mathrm{MMFX}$ 철근(항복 강도 $830 \mathrm{MPa}$ )에 대 한 선행 연구 결과를 $\mathrm{B}$ 급 이음으로 분석하여 $\mathrm{SD} 600$ 철 근의 겹침 이음에 대한 현행 설계기준 ${ }^{1)}$ 의 적용성 평가 에 참고하였다.

이 실험에서는 기존 연구들에서 미비한 $30 \mathrm{MPa}$ 이하 의 보통 강도 콘크리트에 대한 겹침 이음 길이에 중점 을 두었으며, 실시된 실험에 대한 주요한 결과는 다음과 같다.

1) $\mathrm{SD} 600 / \mathrm{D} 13$ 철근의 $\mathrm{B}$ 급 겹침 이음에 대하여 피복 두께(부재의 외면에서 이음 철근면까지의 거리 Fig. 4 참조) $c_{b}=20 \mathrm{~mm}(c=26.5 \mathrm{~mm})$ 이상을 확보할 경우 현 행 설계기준은 안전측이었다.

2) $\mathrm{D} 22$ 철근에 대해서는 $c_{b}=45 \mathrm{~mm}(c=56 \mathrm{~mm})$ 이상인 경우에는 횡보강근이 없는 경우와 있는 경우에 모 두 현행 설계기준이 안전측이었다.

3) $\mathrm{D} 32$ 철근에 대해서는 $c_{b}=45 \mathrm{~mm}(c=61 \mathrm{~mm})$ 이상이 
고 횡보강근이 있는 경우에 현행 설계기준이 안전 측이었다. 횡보강근이 없는 경우에는 추가 연구가 필요하다.

4) $\mathrm{D} 22$ 와 $\mathrm{D} 32$ 의 철근의 경우, 겹침 이음 구간에서 항 복후 연성적인 파괴 모드가 발생하기 위해서는 겹 침 이음 구간에 횡보강근을 배치하여야 한다.

이 연구의 실험 결과와 Seliem 등ㄲㅇㅢ 이전 실험 결 과를 종합하여 분석한 결과 항복 강도 $600 ~ 830 \mathrm{MPa}$ $\mathrm{D} 16$ 이상의 철근의 $\mathrm{B}$ 급 이음에 대한 현행 설계기준 $\left(\mathrm{KCI}^{1)}\right.$ 또는 $\mathrm{ACI} 318^{2)}$ 기준)의 적용성은 다음과 같 이 요약할 수 있다.

$5)$ 횡보강근을 배치하지 않는 경우에는 $c / d_{b}$ 이 $2.5(\mathrm{~min}$ $\left.\left(c_{b}, c_{s o}, c_{s i}\right): \mathrm{D} 22-44 \mathrm{~mm}, \mathrm{D} 32-64 \mathrm{~mm}\right)$ 이상인 경우 현행 설계기준을 안전측으로 사용할 수 있다.

6) 횡보강근을 배치한 경우에는 $K_{t r} / d_{b} \geq 0.25$ 와 $\left(c+K_{t r}\right) /$ $d_{b} \geq 2.25$ 를 만족하는 경우 현행 설계기준을 안전측으 로 사용할 수 있다. 이외의 경우에 대해서는 추가 연 구가 필요하다.

7) $68 \mathrm{MPa}$ 이상의 고강도 콘크리트와 굵은 직경의 철근 에 대해서는 안전율이 작아지므로 추가적인 연구가 필요하다.

이 연구의 실험체와 Seliem 등ㄱㅇㅇㅢ 이전 실험체에 대하 여 $\mathrm{KCI}^{1)}$ (또는 $\mathrm{ACI} 318^{2)}$ ), ACI408R-03 ${ }^{4)}$ Eurocode2 ${ }^{9)}$ 의 예측 결과를 비교한 결과, 횡보강근이 있는 경우와 없는 경우에 대하여 모두 ACI408R- $03^{4}$ 의 기준이 가장 경제적 이며, 안전측으로 사용할 수 있는 것으로 나타났다.

\section{감사의 글}

이 연구는 대한주택공사, 대우건설, 대림산업, 롯데건 설, 삼성물산, 지에스건설, 현대건설, 금호산업, 에이앤유 디자인그룹건축사사무소, 한화건설, 두산건설, 현대산업개 발, 태영건설, 엠코, 쌍용건설, 티엠에스, 한성정밀공업, 윈 윈개발, 코스톤의 연구비 지원을 받아 한국콘크리트학회 에서 수행되었으며 이에 감사드립니다.

\section{참고문헌}

1. 한국콘크리트학회, 콘크리트구조설계기준 해설, 기문당, 2008, 523 pp.

2. ACI 318-08, Building Code Requirements for Structural Concrete and Commentary, ACI Committee 318, American Concrete Institute, 2008, $473 \mathrm{pp}$.

3. ACI Committee 408, 1979, "Suggested Development, Splice, Standard Hook Provisions for Deformed Bars in Tension (ACI 408R-79)," Concrete International, 1979, pp. 44 46.

4. ACI Committee 408, 2003, Bond and Development of Straight Reinforcing Bars in Tension(ACI 408R-03), American Concrete Institute, 2003, pp. 771 782.

5. 이재훈 외, "콘크리트 구조물에 대한 고장력 철근의 적 용성 연구," 최종보고서 KCI-R-10-001, 한국콘크리트학 회, 2010, pp. 221 234.
6. El-Hacha, R., El-Agroudy, H., and Rizkalla, S. H., "Bond Characteristics of High-Strength Steel Reinforcement," ACI Structural Journal, Vol. 103, No. 6, 2006, pp. 1 46.

7. Seliem, H. M., Hosny, A., Rizkalla, S., Zia, P., Briggs, M., Miller, S., Darwin, D., Browning, J., Glass, G. M., Hoyt, K., Donnelly, K., and Jirsa, J. O., "Bond Characteristics of ASTM A1035 Steel Reinforcing Bars," ACI Structural Journal, Vol. 106, No. 4, 2009, pp. 530 539.

8. Orangun, C. O., Jirsa, J. O., and Breen, J. E., "A Reevaulation of Test Data on Development Length and Splices," ACI Journal, March, 1977, pp. 114 122.

9. Eurocode2, Design of Concrete Structures-General Rules and Rules for Buildings, British Standards, 2004, pp. 131 151.

10. Jirsa, J. O., Lutz, L. A., and Gergely, P., "Rationale for Suggested Development, Splice, and Standard Hook Provisions for Deformed Bars in Tension," Concrete International, July, 1979, pp. 47 61.

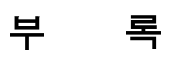

$\mathrm{ACI}$ 408R-03의 겹침 이음 설계규정은 다음과 같다.

$$
\begin{gathered}
\frac{l_{d}}{d_{b}}=\frac{\left[\frac{f_{s}}{f_{c}^{\prime 1 / 4}}-\Phi 2400 \omega\right]}{\left[\Phi 76.3\left(\frac{c \omega+K_{t r}}{d_{b}}\right)\right]} \\
K_{t r}=\left(0.5 t_{d} A_{t r} / s n\right) \sqrt{f_{c}^{\prime}}
\end{gathered}
$$

$t_{d}=0.78 d_{b}+0.22 ; \omega=0.1\left(c_{\max } / c_{\min }\right)+0.9 \leq 1.25 ; \quad A_{t r}=$ 정 착된 철근을 따라 쪼개질 가능성이 있는 면을 가로질러 배치된 간격 $s$ 이내에 있는 횡방향 철근의 전체 단면적, $\mathrm{in}^{2}$; $s=$ 정착 길이 $l_{d}$ 구간 이내에 있는 횡방향 철근의 최대 중 심간 간격, in; $n=$ 쪼개질 가능성이 있는 평면을 따라 정 착되거나 이어지는 철근 또는 철선의 수; $f_{c}^{\prime}=$ 콘크리트 압 축강도, $\mathrm{psi} ; d_{b}=$ 정착 철근 또는 겹침 이음 철근의 공칭직 경, in; $l_{d}=$ 정착 길이 또는 겹침 이음 길이, $\mathrm{in} ; \Phi=$ 강도 감소 계수 $(0.82) ; c=$ 철근 간격 또는 피복 두께에 관련된 치수 $\left(c_{\min }+d_{b} / 2\right), \mathrm{in} ; c_{b}=$ 정착 철근 또는 겹침 이음 철근 과 실험체 인장면의 순피복 두께, $\mathrm{in} ; c_{s o}=$ 정착 철근 또는 겹침 이음 철근과 실험체 측면의 순피복 두께, $\mathrm{in} ; c_{s i}=$ 정 착 철근 또는 겹침 이음 철근 사이 순간격의 $1 / 2, \mathrm{in} ; c_{s}=$ $\min \left(c_{s i}+0.25, c_{s o}\right)$, in; $c_{\min }=\min \left(c_{b}, c_{s}\right)$, in; $c_{\max }=\max \left(c_{b}\right.$, $\left.c_{s}\right)$, in; $\left(c \omega+K_{t r}\right) / d_{b} \leq 4.0$ 이며, $\mathrm{A}$ 급 이음과 $\mathrm{B}$ 급 이음에 대 한 분류 없이 $l_{d}$ 를 겹침 이음 길이로 사용한다.

Eurocode2의 겹침 이음 설계규정은 다음과 같다.

$$
\begin{aligned}
& l_{0}=\alpha_{2} \alpha_{3} \alpha_{6} l_{b, r e q} \geq l_{0, \text { min }} \\
& \begin{aligned}
\alpha_{2}=1-0.15\left(c_{d}-\Phi\right) / \Phi & \geq 0.7 \\
& \leq 1.0
\end{aligned}
\end{aligned}
$$




$$
\begin{aligned}
& \begin{aligned}
\alpha_{3}=1-K \lambda \geq 0.7 \\
\quad \leq 1.0
\end{aligned} \\
& \begin{aligned}
l_{b, r q d}=\frac{\Phi}{4} \frac{\sigma_{s d}}{f_{b d}}=\frac{\Phi}{4} \frac{f_{s} / \gamma_{s}}{f_{b d}}=\frac{\Phi}{4} \frac{f_{s} / 1.15}{f_{b d}} \\
f_{b d}=2.25 \eta_{2} f_{c t d} \\
f_{c t d}=\alpha_{c t} \frac{f_{c t k, 0.05}}{\gamma_{c}}=1.0 \frac{0.7 f_{c t m}}{\gamma_{c}}=\frac{0.7}{1.5}(0.3) f_{c k}^{2 / 3}
\end{aligned}
\end{aligned}
$$

$l_{0}=$ 겹침 이음 길이, $\mathrm{mm} ; \Phi=$ 정착 철근 또는 겹침 이 음 철근의 공칭 직경, $\mathrm{mm} ; \alpha_{2}=$ 철근 간격 또는 피복 두 께 관련 계수 ; $\alpha_{3}=$ 주철근에 용접되지 않은 횡보강 철 근 관련 계수 ; $\alpha_{6}=\left(\rho_{1} / 25\right)^{0.5}, 1.0$ 이상 1.5 이하로 제한되 며 $\rho_{1}$ 은 겹침 이음 길이의 중앙에서 $0.65 l_{0}$ 구간 내에 겹 침 이음된 철근 면적의 비율 $(\%)$ 이다. 이 실험과 같이 $\rho_{1}$ 이 $50 \%$ 이상일 경우 $\alpha_{6}=1.5$ 이다. $l_{0, \min }=\max \left(0.3 \alpha_{6} l_{b, r q d}, 15 \Phi\right.$,
200), $\left.\mathrm{mm} ; c_{d}=\min \left(c_{b}, c_{s o}, c_{s i}\right) ; K=\mathrm{i}\right)$ 횡보강 철근의 모 서리에 배치된 겹침 이음 철근, 0.1 , ii)모서리를 제외한 횡 보강 철근의 내부에 배치된 겹침 이음 철근, 0.05 , iii) 횡 보강 철근이 겹침 이음 철근과 콘크리트 표면 사이에 배 치되지 않은 경우, $0 ; \lambda=\left(\Sigma A_{s t}-\Sigma A_{s t, \mathrm{~min}}\right) / A_{s} ; \Sigma A_{s t}=l_{0}$ 에 걸 쳐서 존재하는 횡보강 철근의 총 단면적, $\mathrm{mm}^{2} ; \Sigma A_{s t, \mathrm{~min}}$ $=1.0 A_{s}, \mathrm{~mm}^{2} ; A_{s}$ 겹침 이음 철근 1 개의 최대 단면적, $\mathrm{mm}^{2}$; $\sigma_{s d}=$ 철근의 설계 응력, $\mathrm{MPa} ; \gamma_{s}=$ 철근 또는 프리스트레 싱 강재에 대한 부분 안전 계수(1.15); $f_{b d}=$ 설계 부착 강 도, $\mathrm{MPa} ; \eta_{2}=$ 겹침 이음 철근 직경 관련 계수, D32 이하 일 경우 1.0, 그 외의 경우 $(132-\Phi) / 100 ; f_{c t d}=$ 콘크리트 의 설계 인장강도, $\mathrm{MPa} ; \alpha_{c t}=$ 인장강도에 미치는 장기적 인 영향이나 재하 방식으로 인한 불리한 영향을 고려하 기 위한 계수(1.0); $\gamma_{c}=$ 콘크리트에 대한 부분 안전 계수 (1.5) $; f_{c t k, 0.05}=5 \%$ 분위값, $\mathrm{MPa} ; f_{c t m}=$ 평균 콘크리트 인 장강도, $\mathrm{MPa}, f_{c k}=28$ 일의 콘크리트 특성 압축강도, $\mathrm{MPa}$; 겹침 이음 길이를 설계할 때 적용 가능한 철근의 설계 기준항복 강도는 $600 \mathrm{MPa}$ 로 제한된다.

요 약 이 연구에서는 SD600 철근 B급 이음에 대한 현행 설계기준의 적용성 평가를 위하여 실험적 연구가 수행되 었다. 단순 지지된 12 개의 $\mathrm{B}$ 급 겹침 이음 실험체에 단순 증가 하중을 가하여 실험하였다. 주요 변수는 겹침 이음 철근 직경, 콘크리트 피복 두께, 콘크리트 강도, 횡보강 철근 간격이다. 콘크리트는 $24 \mathrm{MPa}$ 의 보통 강도 콘크리트와 $60 \mathrm{MPa}$ 의 고강도 콘크리트를 사용하였다. 대부분의 실험체는 현행 설계기준의 $\mathrm{B}$ 급 이음 길이를 만족하도록 설계하였다. 실험 에서 발현된 철근 응력의 평균을 현행 $\mathrm{KCI}$ 설계기준의 예측 철근 응력과 비교하였으며, 그 결과를 통하여 SD600 철근 에 대한 현행 설계기준의 적용성을 평가하였다. 현행 설계기준은 모든 D13 겹침 이음과 횡보강 철근이 배치된 $\mathrm{D} 22$, $\mathrm{D} 32$ 겹침 이음에 대하여 안전측이었다. 직경 $\mathrm{D} 22$ 이상 철근의 겹침 이음은 횡보강 철근의 사용이 권장되는 결과를 나 타내었다. 고강도 콘크리트를 사용한 $\mathrm{D} 22, \mathrm{D} 32$ 철근의 겹침 이음은 안전한 경향성을 보였으나, 확실한 검증을 위하여 추가적인 연구가 필요하다.

핵심용어 :SD600, 교강도 철근, 겹침 이음 길이, 부착, $\mathrm{B}$ 급 이음 